\title{
Impact of Serotonin 2C Receptor Null Mutation on Physiology and Behavior Associated with Nigrostriatal Dopamine Pathway Function
}

\author{
Luna Abdallah, ${ }^{1 *}$ Stephen J. Bonasera, ${ }^{2 \star}$ F. Woodward Hopf, ${ }^{8}$ Laura 0 'Dell, ${ }^{3}$ Marco Giorgetti, ${ }^{5}$ Minke Jongsma, ${ }^{4}$ \\ Scott Carra, ${ }^{1}$ Massimo Pierucci, ${ }^{6}$ Giuseppe Di Giovanni, ${ }^{6}$ Ennio Esposito, ${ }^{6}$ Loren H. Parsons, ${ }^{7}$ Antonello Bonci, ${ }^{8}$ and \\ Laurence H. Tecott ${ }^{1}$ \\ ${ }^{1}$ Department of Psychiatry, University of California, San Francisco, San Francisco, California 94158, ${ }^{2}$ Division of Geriatrics, Department of Medicine, \\ University of California, San Francisco, San Francisco, California 94143, ${ }^{3}$ Department of Psychology, University of Texas, El Paso, El Paso, Texas 79968, \\ ${ }^{4}$ Brains On-Line, San Francisco, California 94158, ${ }^{5}$ Division of Pharmacology, Amgen, South San Francisco, California 94080, ${ }^{6}$ Istituto Di Ricerche \\ Farmacologiche "Mario Negri," Consorzio “Mario Negri Sud," 66030 Santa Maria Imbaro, Chieti, Italy, ${ }^{7}$ Committee on the Neurobiology of Addictive \\ Disorders, SP30 -2120, The Scripps Research Institute, La Jolla, California 92037, and 8Ernest Gallo Clinic and Research Center, University of California, San \\ Francisco, Emeryville, California 94608
}

The impact of serotonergic neurotransmission on brain dopaminergic pathways has substantial relevance to many neuropsychiatric disorders. A particularly prominent role has been ascribed to the inhibitory effects of serotonin $2 \mathrm{C}$ receptor $\left(5\right.$ - $\left.\mathrm{HT}_{2 \mathrm{C}} \mathrm{R}\right)$ activation on physiology and behavior mediated by the mesolimbic dopaminergic pathway, particularly in the terminal region of the nucleus accumbens. The influence of this receptor subtype on functions mediated by the nigrostriatal dopaminergic pathway is less clear. Here we report that a null mutation eliminating expression of $5-\mathrm{HT}_{2 \mathrm{C}} \mathrm{Rs}$ produces marked alterations in the activity and functional output of this pathway. 5- $\mathrm{HT}_{2 \mathrm{C}} \mathrm{R}$ mutant mice displayed increased activity of substantia nigra pars compacta (SNc) dopaminergic neurons, elevated baseline extracellular dopamine concentrations in the dorsal striatum (DSt), alterations in grooming behavior, and enhanced sensitivity to the stereotypic behavioral effects of D-amphetamine and GBR 12909. These psychostimulant responses occurred in the absence of phenotypic differences in drug-induced extracellular dopamine concentration, suggesting a phenotypic alteration in behavioral responses to released dopamine. This was further suggested by enhanced behavioral responses of mutant mice to the $\mathrm{D}_{1}$ receptor agonist SKF 81297. Differences in DSt $D_{1}$ or $D_{2}$ receptor expression were not found, nor were differences in medium spiny neuron firing patterns or intrinsic membrane properties following dopamine stimulation. We conclude that $5-\mathrm{HT}_{2 \mathrm{C}} \mathrm{Rs}$ regulate nigrostriatal dopaminergic activity and function both at SNc dopaminergic neurons and at a locus downstream of the DSt.

\section{Introduction}

The prominence of central serotonin (5-HT) and dopamine (DA) systems in the pathophysiology and treatment of neuropsychiatric disorders underscores the importance of understanding how these systems interact. It is established that the serotonin system regulates the mesoaccumbal and nigrostriatal dopaminergic pathways (Esposito, 2006; Alex and Pehek, 2007; Fink and Göthert, 2007). Serotonergic cell bodies in the raphe nuclei project to the substantia nigra pars compacta $(\mathrm{SNc})$ and ventral tegmental area (VTA) and their terminal projections within the

\footnotetext{
Received Aug. 15, 2008; revised Dec. 19, 2008; accepted Jan. 12, 2009.

This work was supported by National Institutes of Health (NIH) Grant MH019552-12 (L.A.); NIH Grant MH065983 and the Brookdale National Fellowship Program (S.J.B.); NIH Grants AA012294, AA012294, AA014619, and DA019962 (L.H.P., L.O'D.); funds provided by the State of California for medical research on alcohol and substance abuse through the University of California, San Francisco (A.B., F.W.H.); and NIH Grant DA11177 and National Alliance for Research on Schizophrenia and Depression (L.H.T.).

*L.A. and S.J.B. contributed equally to this work.

Correspondence should be addressed to Laurence H. Tecott at the above address. E-mail: larry.tecott@ucsf.edu. DOI:10.1523/JNEUROSCI.3905-08.2009

Copyright $\odot 2009$ Society for Neuroscience $\quad 0270-6474 / 09 / 298156-10 \$ 15.00 / 0$
}

dorsal striatum (DSt) and nucleus accumbens (NAc), respectively (Bobillier et al., 1975; Fibiger and Miller, 1977; Hervé et al., 1987; Nedergaard et al., 1988). The serotonin system regulates the functional output of these pathways, but precise mechanisms remain to be clarified (Kelland et al., 1990, 1993; De Deurwaerdère et al., 1996; Saito et al., 1996).

Among the 14 serotonin receptor subtypes, the serotonin $2 \mathrm{C}$ receptor $\left(5-\mathrm{HT}_{2 \mathrm{C}} \mathrm{R}\right)$ is believed to play a particularly prominent role in the modulation of dopamine function (Di Matteo et al., 2002b; Esposito, 2006). 5- $\mathrm{HT}_{2 \mathrm{C}} \mathrm{R}$ mRNA is abundantly expressed on GABAergic neurons within the SNc and VTA and in the DSt and NAc (Mengod et al., 1990; Ward and Dorsa, 1996; EberleWang et al., 1997). 5- $\mathrm{HT}_{2 \mathrm{C}}$ Rs are implicated in tonic and phasic modulation of the mesoaccumbal dopamine pathway. Pharmacological activation of $5-\mathrm{HT}_{2 \mathrm{C}} \mathrm{Rs}$ inhibits firing rates of VTA neurons and DA release within the NAc (Prisco et al., 1994; Di Matteo et al., 1998; Di Giovanni et al., 1999).

How $5-\mathrm{HT}_{2 \mathrm{C}} \mathrm{Rs}$ participate in the regulation of nigrostriatal DA system function is less clear. It has been suggested that $5-\mathrm{HT}_{2 \mathrm{C}} \mathrm{Rs}$ have less influence on the nigrostriatal than on the 
mesoaccumbal DA pathway (Di Matteo et al., 2001). This is based on reports that pharmacological manipulations of $5-\mathrm{HT}_{2 \mathrm{C}} \mathrm{Rs}$ produce relatively modest effects on $\mathrm{SNc}$ dopaminergic neuronal activity and DA release in the DSt (Kelland et al., 1990; Di Matteo et al., 1999; Di Giovanni et al., 2000). However, other studies indicate that $5-\mathrm{HT}_{2 \mathrm{C}} \mathrm{R}$ agonist and antagonist treatments impact DA release in the DSt and NAc in a similar manner (De Deurwaerdère and Spampinato, 1999; Gobert et al., 2000; Porras et al., 2002; De Deurwaerdère et al., 2004; Navailles et al., 2004). These conflicting results may be attributable to the use of different $5-\mathrm{HT}_{2 \mathrm{C}} \mathrm{R}$ ligands with varying specificity and modes of action.

It is possible that the impact of $5-\mathrm{HT}_{2 \mathrm{C}} \mathrm{R}$ function on behaviors regulated by the nigrostriatal DA system may occur through the actions of these receptors within the SNc. However, $5-\mathrm{HT}_{2 \mathrm{C}}$ Rs are also expressed in a number of basal ganglia structures to which the DSt projects (Wright et al., 1995; Eberle-Wang et al., 1997). 5- $\mathrm{HT}_{2 \mathrm{C}}$ Rs expressed in basal ganglia structures outside the DSt have previously been implicated in movement disorders such as oral dyskinesias (Eberle-Wang et al., 1996).

Here, we use a genetic approach to investigate the role of $5-\mathrm{HT}_{2 \mathrm{C}} \mathrm{Rs}$ in physiology and behaviors associated with nigrostriatal dopamine pathway function. This was pursued in studies of mice bearing a null mutation of the $h t r 2 c$ gene by a combination of electrophysiological, pharmacological, neurochemical, and behavioral approaches.

\section{Materials and Methods}

Animals. Mice were produced in our rodent colony $\left(5-\mathrm{HT}_{2 \mathrm{C}} \mathrm{R}\right.$ mutant and littermate wild-type controls) or were purchased from The Jackson Laboratory (wild-type C57BL/6J mice). The generation of 5- $\mathrm{HT}_{2 \mathrm{C}} \mathrm{R}$ null mutant mice has been described in detail previously (Tecott et al., 1995). The htr $2 c^{-}$mutation is congenic on a C57BL/6J background and maintained by mating $5-\mathrm{HT}_{2 \mathrm{C}} \mathrm{R}$ heterozygous females and $\mathrm{C} 57 \mathrm{BL} / 6 \mathrm{~J}$ males. Animals were weaned at 3 weeks and group housed in standard polypropylene cages $(16 \times 27 \times 12 \mathrm{~cm})$ with $3-5$ littermates per cage. Mice had ad libitum access to water and chow (PicoLab Mouse Diet 20, Purina Mills). The housing facility was maintained at $22^{\circ} \mathrm{C}$ with a $12-\mathrm{h}-\mathrm{on} / 12-$ h-off lighting schedule, lights on at 7:00 A.M. Unless otherwise indicated, these studies used male mice 2.5-4 months old.

Drugs. GBR 12909 (a selective inhibitor of the dopamine reuptake transporter, Sigma-Aldrich; Tocris Bioscience) was dissolved by gentle heating and sonication. Animals received GBR 12909 doses of 0, 3, 10, and $30 \mathrm{mg} / \mathrm{kg}$. SB 206553 (a 5- $\mathrm{HT}_{2 \mathrm{C}} \mathrm{R}$ inverse agonist, Sigma-Aldrich) at doses of 0 and $5 \mathrm{mg} / \mathrm{kg}$ were similarly prepared. D-Amphetamine (SigmaAldrich) was used at doses of $0,2.5,5$, and $10 \mathrm{mg} / \mathrm{kg}$. Quinpirole (a selective $\mathrm{D}_{2}$ receptor agonist, Tocris Bioscience) was administered at doses of 0, 0.6, 2, and $6 \mathrm{mg} / \mathrm{kg}$. SKF 81297 (a selective $\mathrm{D}_{1}$ receptor agonist, Tocris Bioscience) was administered at 0 and $10 \mathrm{mg} / \mathrm{kg}$. All mice received intraperitoneal doses of drug in $10 \mu \mathrm{l} / \mathrm{g}$ injection volumes. All vehicles used in these studies were normal saline.

Single-cell recording procedures. Mice ( $n=8$ wild type, $n=85-\mathrm{HT}_{2 \mathrm{C}} \mathrm{R}$ mutant) were anesthetized with chloral hydrate $(400 \mathrm{mg} / \mathrm{kg}$, i.p.) and mounted on a stereotaxic apparatus (SR-6, Narishige). Body temperature was maintained at $36-37^{\circ} \mathrm{C}$. A 28 gauge needle was placed in a lateral tail vein through which additional anesthetic was administered as required. The skull overlying both the SNc and the VTA was removed. The coordinates (relative to the interaural line) for recording electrode placement were as follows: $\mathrm{SNc}$, anteroposterior (AP) $0.16-0.72 \mathrm{~mm}$, mediolateral (ML) 1.1-1.5 mm, dorsoventral (DV) $3.8-4.8 \mathrm{~mm}$; VTA, AP 0.16-0.72 mm, ML 0.1-0.5 mm, DV 3.8-4.8 mm (Paxinos and Franklin, 2001). Extracellular recordings were obtained using single-barrel micropipettes (4-7 M $\Omega$ resistance containing 2\% pontamine sky blue dye in $2 \mathrm{M} \mathrm{NaCl}$ ). DA neurons were identified by standard electrophysiological criteria (Bunney et al., 1973; Grace and Bunney, 1980; Wang, 1981; Sanghera et al., 1984). Spike activity was detected using a highimpedance amplifier connected to an analog oscilloscope, audio moni- tor, and window discriminator. Unit activity was converted to an integrated histogram by a rate-averaging algorithm and displayed as spikes per $10 \mathrm{~s}$ intervals. The basal electrical activity of each DA neuron was recorded for at least $5 \mathrm{~min}$ to establish the baseline firing rate and bursting activity. The number of spontaneously active DA neurons within both the SNc and the VTA regions were counted by lowering the electrode through a block of tissue, which could be reproducibly located from animal to animal. Twelve electrode tracks (separated from each other by $200 \mu \mathrm{m}$ ), whose sequence was kept constant from animal to animal, were made in each region. Only cells whose electrophysiological characteristics matched those previously established for midbrain DA neurons were sampled. After each experiment, the recording site was marked by injection of pontamine sky blue dye using a $-20 \mu \mathrm{A}$ current for $10 \mathrm{~min}$. Brains were removed and placed in $10 \%$ buffered formalin for $2 \mathrm{~d}$ before histological examination. Frozen sections were cut at $40 \mu \mathrm{m}$ intervals and stained with neutral red. Microscopic examination of the sections was performed to verify that the electrode tip was in the SNc or the VTA.

Single-cell recording data analysis. The mean number of cells per track was calculated by dividing the total number of DA neurons encountered by the total number of electrode tracks performed for either the SNc or the VTA. Burst analysis of DA neurons was performed using RISI (Symbolic Logic). A total of 500-1200 consecutive spikes were recorded for each neuron in both wild-type and mutant mice. Burst firing, when present, was detected using an algorithm similar to that previously described (Grace and Bunney, 1984). The mean percentage of spikes occurring in bursts was used as a measure of bursting activity. Differences in the number of cells per track, the basal firing rate, and the bursting activity between wild-type and mutant mice were analyzed by two-tailed Student's $t$ test. All statistical analyses were performed with StatView version 5.0.1 (SAS Institute).

Microdialysis probe construction and implantation. Probe implantation occurred 12-48 h before dialysis testing. Concentric microdialysis probes consisted of 23 gauge stainless steel and silica capillary tubing. The dialysis membrane (inner diameter $240 \mu \mathrm{m}$, outer diameter $290 \mu \mathrm{m}, 2$ $\mathrm{mm}$ exposed for striatum, $1 \mathrm{~mm}$ exposed for NAc, AN 69HF, Hospal) consisted of polyacrylonitrile/sodium methylsulfonate copolymer with an average pore size of $29 \AA$. Mice were anesthetized using inhalational (isoflurane or halothane, $2 \%, 800 \mathrm{ml} / \mathrm{min}_{2}$ ) or injectable (ketamine $100 \mathrm{mg} / \mathrm{kg}$-xylazine $10 \mathrm{mg} / \mathrm{kg}$, i.p.) agents. Lidocaine was used for local anesthesia. The animals were placed in a stereotaxic frame (Kopf Instruments), and probes were inserted into the striatum $(+0.7 \mathrm{AP},-2.0 \mathrm{ML}$, $-3.0 \mathrm{DV}$ for standard microdialysis; +0.5 AP, +2.0 ML, $-5.0 \mathrm{DV}$ for no net flux microdialysis) or NAc ( $-1.5 \mathrm{AP},+0.8 \mathrm{ML},-5.3 \mathrm{DV}$, only no net flux microdialysis) per established atlas coordinates (Paxinos and Franklin, 2001). Probes were secured to the skull using dental cement. Mice were then returned to a standard polycarbonate cage with sawdust bedding and allowed to regain consciousness.

Standard microdialysis procedure. Experiments were performed 24-48 $\mathrm{h}$ after surgery. On the day of the experiment, the microdialysis probes were connected with flexible PEEK tubing to a microperfusion pump (Harvard Apparatus, PHD 2000) and perfused with artificial CSF (aCSF), containing $146 \mathrm{~mm} \mathrm{NaCl}, 2.9 \mathrm{~mm} \mathrm{KCl}, 1.2 \mathrm{~mm} \mathrm{CaCl}_{2}$, and $1.1 \mathrm{~mm}$ $\mathrm{MgCl}_{2}$, at a flow rate of 1.0-1.5 $\mu \mathrm{l} / \mathrm{min}$ (for GBR 12909 microdialysis experiments, aCSF also contained $2 \mathrm{mM} \mathrm{Na}_{2} \mathrm{HPO}_{4}$, pH 7.40). Microdialysis samples were collected at 15-20 min intervals into vials (for GBR 12909 study, containing $7.5 \mu \mathrm{l}$ of $0.02 \mathrm{M}$ formic acid). Microdialysis samples were collected by an automated fraction collector (Univentor 820 ) and stored at $-80^{\circ} \mathrm{C}$. Drug treatment (either D-amphetamine or GBR 12909) was administered immediately before collection of the sixth sample. After the experiment, mice were killed and their brains removed and incubated for $3 \mathrm{~d}$ in $4 \%$ paraformaldehyde. The probe position was histologically verified in coronal brain sections (Paxinos and Franklin, 2001).

No net flux microdialysis procedure. aCSF consisted of $149 \mathrm{~mm} \mathrm{NaCl}$, $2.8 \mathrm{~mm} \mathrm{KCl}, 1.2 \mathrm{~mm} \mathrm{CaCl}_{2}, 1.2 \mathrm{mM} \mathrm{MgCl}_{2}, 0.25 \mathrm{~mm}$ ascorbic acid, and 5.4 mM D-glucose, $\mathrm{pH}$ 7.3. Perfusate flow rate to both probes was $0.2 \mu \mathrm{l} / \mathrm{min}$ for the first 10 postsurgical hours, and then increased to $0.6 \mu \mathrm{l} / \mathrm{min} 1 \mathrm{~h}$ before the start of dialysate collection and for the remainder of the ex- 
periment. Following equilibration, six baseline samples were collected at $10 \mathrm{~min}$ intervals. The perfusate was switched to aCSF containing $5 \mathrm{~nm}$ DA and allowed to equilibrate for $30 \mathrm{~min}$ followed by dialysate collection for $30 \mathrm{~min}$. This same procedure was subsequently used for perfusates containing 10 and $20 \mathrm{~nm}$ dopamine. Following collection, dialysate samples were immediately frozen and stored at $-70^{\circ} \mathrm{C}$.

DA measurements. Dialysate aliquots were injected onto a reversed phase column ( $3 \mu \mathrm{m} \mathrm{C18} \mathrm{stationary} \mathrm{phase,} \mathrm{multiple} \mathrm{vendors).} \mathrm{Samples}$ were eluted with a mobile phase (acetonitrile, phosphate buffer, and an ion-pairing agent, ESA) for D-amphetamine studies; NaAc buffer (4.1 $\mathrm{g} / \mathrm{L}$ ) with $\mathrm{MeOH}(2.5 \% \mathrm{v} / \mathrm{v})$, Titriplex ( $150 \mathrm{mg} / \mathrm{L})$, OSA (150 mg/L), and TMACl (150 mg/L, pH 4.1) for GBR 12909 studies, and 17\% acetonitrile (v/v) in a $25 \mathrm{~mm} \mathrm{NaH}_{2} \mathrm{PO}_{4}$ buffer containing $0.1 \mathrm{~mm} \mathrm{Na}_{2}$-EDTA, $1.6 \mathrm{~mm}$ 1-decanesulfonic acid, and $14.4 \mathrm{~mm}$ triethylamine, $\mathrm{pH} 3.9$, for no net flux studies. Pump flow rates were $0.25 \mathrm{ml} / \mathrm{min}, 0.35 \mathrm{ml} / \mathrm{min}$, and $35 \mu \mathrm{l} / \mathrm{min}$ for D-amphetamine, GBR 12909, and no net flux studies, respectively. For D-amphetamine studies, DA was detected using an amperometric cell (Model 5041, ESA) at a potential of $+175 \mathrm{mV}$ coupled to a coulometric detector (Coulochem II, ESA). For GBR 12909 studies, DA was detected using a glassy carbon electrode at a potential of $+500 \mathrm{mV}$ ( $\mathrm{vs} \mathrm{Ag} / \mathrm{AgCl}$ reference electrode) coupled to an Intro detector (Antec Leyden). For no net flux studies, DA was detected using a glassy carbon electrode at a potential of $+700 \mathrm{mV}$ (vs $\mathrm{Ag} / \mathrm{AgCl}$ reference electrode) as controlled by an amperometric detector (EG\&G 400, Princeton Applied Research). On-column limits of quantification were $2 \mathrm{fmol}$ (D-amphetamine), 0.3 fmol (GBR 12909), and $0.5 \mathrm{fmol}$ (no net flux).

For D-amphetamine and GBR 12909 studies, basal DA levels were defined as the average of the first five samples. To determine the effect of genotype on DA release after treatment, repeated-measures ANOVAs were performed on values obtained during the $180 \mathrm{~min}$ following drug injection (time intervals 6-14).

Syntactic grooming studies. Syntactic grooming chains (as described by Aldridge and Berridge, 1998) were observed in cohorts of 2-3-monthold male mice ( $n=9$ wild type, $n=8$ mutant) following gentle misting of their back flanks with room temperature tap water. Mouse grooming activity was videotaped from two directions for $10 \mathrm{~min}$. All mice were tested for 10 consecutive days between 1:00 and 4:00 P.M. daily. Grooming videos were digitized to MPEG, and scored by a single investigator in a blinded manner using Observer Video-Pro 5.0 (Noldus). At least 15 min of total grooming time was evaluated for each mouse. As described, completed syntactic chains could have multiple morphologies, but all chains had to begin in phase 1 , be followed by either phase 2 , phase 3 , or phase $2-$ phase 3 , and then end with phase 4 . Incomplete chains always began with phase 1, but did not evolve according to the above criteria. Nonsyntactic grooming states were scored for all grooming behavior not classified as either a completed or broken syntactic chain. Differences in grooming behavior properties were evaluated by Student's $t$ test with $p$ values adjusted for multiple comparisons using Bonferroni corrections.

Locomotor activity monitoring. Animals were singly housed in 16 standard polypropylene cages $(45 \times 24 \times 17 \mathrm{~cm})$ surrounded by $8 \times 4$ photobeam activity monitoring brackets (FlexField, San Diego Instruments). Bedding was placed on the cage floor; food and water were provided ad libitum. Mice were acclimated to these home cages for $4-5 \mathrm{~d}$ before drug administration. Mice received intraperitoneal injections of saline vehicle between 1:00 and 3:00 P.M. each day before drug administration to habituate them to injections. At each treatment dose, repeated-measures ANOVA was conducted on values between 0 and 90 min after the injection with time as a within-subject factor and genotype and treatment as between-subject factors. In addition, univariate ANOVA was conducted on peak locomotor activity (LA) with genotype and treatment as between-subject factors.

Stereotypic behavior measurement. The same habituation protocol for LA was followed. Home cage behavior was video recorded for 3-4 min at intervals chosen based on observations from pilot studies. These intervals were 30 and 90 min after GBR 12909 and GBR 12909/SB 206553 injection, 30 and $75 \mathrm{~min}$ after 2.5 and $5 \mathrm{mg} / \mathrm{kg} \mathrm{D}$-amphetamine injection, and 30 and $110 \mathrm{~min}$ after $10 \mathrm{mg} / \mathrm{kg}$ D-amphetamine injection. For SKF 81297 and quinpirole treatments, mice were videotaped for $10 \mathrm{~min}(10 \mathrm{~min}$ after drug injection). Videotaped behavior trials were converted to digital video and scored for stereotypy. Differences in motor and stereotypy responses between GBR 12909 and D-amphetamine have previously been noted (Hooks et al., 1994); we thus used stereotypy rating scales appropriate for each treatment. Motor stereotypy in response to GBR 12909 treatment was scored using a modified version of a previously published protocol (Creese and Iversen, 1973). Six distinct behaviors were noted: asleep (score 1), awake inactive (score 2), awake locomotion (score 3), awake "route tracing" locomotion (score 4), intermittent oral/grooming stereotypies (score 5), and continuous oral/grooming stereotypies (score 6). Motor stereotypy in response to D-amphetamine treatment was scored using a modified version of a previously published protocol (Chartoff et al., 2001). Eight distinct behaviors were noted: no movement, ambulation, oral stereotypy, sniffing, rearing, vigorous grooming, taffy pulling, and climbing. For both GBR 12909 and D-amphetamine treatment, behaviors were scored at the start and every $10 \mathrm{~s}$ into the trial. For SKF 81297 and quinpirole treatments, videos were scored for the entire $10 \mathrm{~min}$ recording period. Investigators were blinded to genotype and drug treatment status. For each treatment dose, repeated-measures ANOVA was conducted with time as a within-subject factor and genotype and treatment as between-subject factors.

Slice preparation and electrophysiology. Male P22-P28 mice were anesthetized with halothane and decapitated, the brain was rapidly removed, and coronal slices $(300 \mu \mathrm{m})$ were cut in $4^{\circ} \mathrm{C}$ aCSF using a VT1000S (Leica). Slices were recovered at $32^{\circ} \mathrm{C}$ in carbogen-bubbled aCSF $(126$ $\mathrm{mm} \mathrm{NaCl}, 2.5 \mathrm{~mm} \mathrm{KCl}, 1.2 \mathrm{~mm} \mathrm{NaH}{ }_{2} \mathrm{PO}_{4}, 1.2 \mathrm{~mm} \mathrm{MgCl}_{2}, 2.4 \mathrm{~mm} \mathrm{CaCl}_{2}$, $18 \mathrm{~mm} \mathrm{NaHCO}_{3}$, and $11 \mathrm{~mm}$ glucose, with $\mathrm{pH} 7.2-7.4,301-305 \mathrm{mOsm}$ ) for $30 \mathrm{~min}$ to $5 \mathrm{~h}$. During experiments, slices were submerged and continuously perfused (using a peristaltic pump, $\sim 2 \mathrm{ml} / \mathrm{min}$ ) with carbogen-bubbled aCSF warmed to $31-32^{\circ} \mathrm{C}$ and supplemented with CNQX (10 $\mu \mathrm{M}$, to block AMPA-type glutamate miniature EPSPs) and picrotoxin $\left(50 \mu \mathrm{M}\right.$, to block $\mathrm{GABA}_{\mathrm{A}}$ receptors). All reagents were bath applied.

Whole-cell recordings were made from DSt medium spiny neurons (MSNs), identified as previously described (Hopf et al., 2003), using a potassium methanesulfonate-based internal solution $[\mathrm{KOH} 0.98 \%(\mathrm{v} / \mathrm{v})$, methanesulfonic acid $0.76 \%(\mathrm{v} / \mathrm{v})$, hydrochloric acid $0.18 \%(\mathrm{v} / \mathrm{v}), 20 \mathrm{mM}$ HEPES, $0.3 \mathrm{~mm}$ EGTA, $2.8 \mathrm{~mm} \mathrm{NaCl}, 2.5 \mathrm{mg} / \mathrm{ml} \mathrm{MgATP}$, and $0.25 \mathrm{mg} / \mathrm{ml}$ GTP, pH 7.2-7.4, 275-285 mOsm]. Current pulses were applied using Clampex 9.2 and 700A patch amplifier in current-clamp mode (Molecular Devices). Series resistance correction was 15-25 M $\Omega$. The resting membrane potential was determined just after breaking into a neuron, and each neuron was then brought to a resting potential of approximately $-80 \mathrm{mV}$ by passage of DC current via the patch amplifier before collection of firing data.

To generate action potentials, neurons in current clamp were depolarized with a series of seven or eight $300 \mathrm{~ms}$ current pulses, with $20 \mathrm{pA}$ between each current step, where the initial current step for each neuron was just subthreshold for firing. This series of current pulses was delivered every $30 \mathrm{~s}$, alternating with a $33.3 \mathrm{pA}$ hyperpolarizing pulse. Patchclamp data were collected at $15 \mathrm{kHz}$ and filtered at $2 \mathrm{kHz}$. All data were analyzed using Clampfit (Axon Instruments). To calculate percentage change in spiking, a current pulse was selected that exhibited two spikes at baseline, or three spikes if no current step evoked two spikes. The same current pulse was used for time points before and after drug addition. Spike firing rates during the $3 \mathrm{~min}$ before addition of the reagent were averaged and this value normalized to $100 \%$. Statistical significance was determined for the average spike firing change during the last 2 min of exposure to reagents All statistics were performed using a two-tailed, unpaired Student's $t$ test.

Receptor autoradiography. Mice underwent rapid decapitation, brain dissection, and tissue freezing on powdered dry ice. Coronal sections (20 $\mu \mathrm{m}$ thickness) were cut on a cryostat with appropriate histological reference slides and stored desiccated at $-20^{\circ}$ until ready for tissue processing. All radioligand binding reactions occurred within 1 week of cutting the sections. Sections were preincubated in buffer $(50 \mathrm{~mm}$ Tris- $\mathrm{HCl}, \mathrm{pH}$ 7.4, $120 \mathrm{~mm} \mathrm{NaCl}, 5 \mathrm{~mm} \mathrm{KCl}, 2 \mathrm{~mm} \mathrm{CaCl} 2,1 \mathrm{~mm} \mathrm{MgCl}_{2}$, and either $40 \mathrm{~nm}$ ketanserin (to block nonspecific $5-\mathrm{HT}_{2 \mathrm{~A}}$ and $5-\mathrm{HT}_{2 \mathrm{C}}$ receptor binding in the $\mathrm{D}_{1}$ reaction) or $0.5 \mu \mathrm{M}$ DTG, $0.1 \mu \mathrm{M}$ pindolol (to block nonspecific $\sigma$ and $5-\mathrm{HT}_{1 \mathrm{~A}} \mathrm{R}$ receptor binding in the $\mathrm{D}_{2}$ reaction) for $1 \mathrm{~h}$ before indirect 

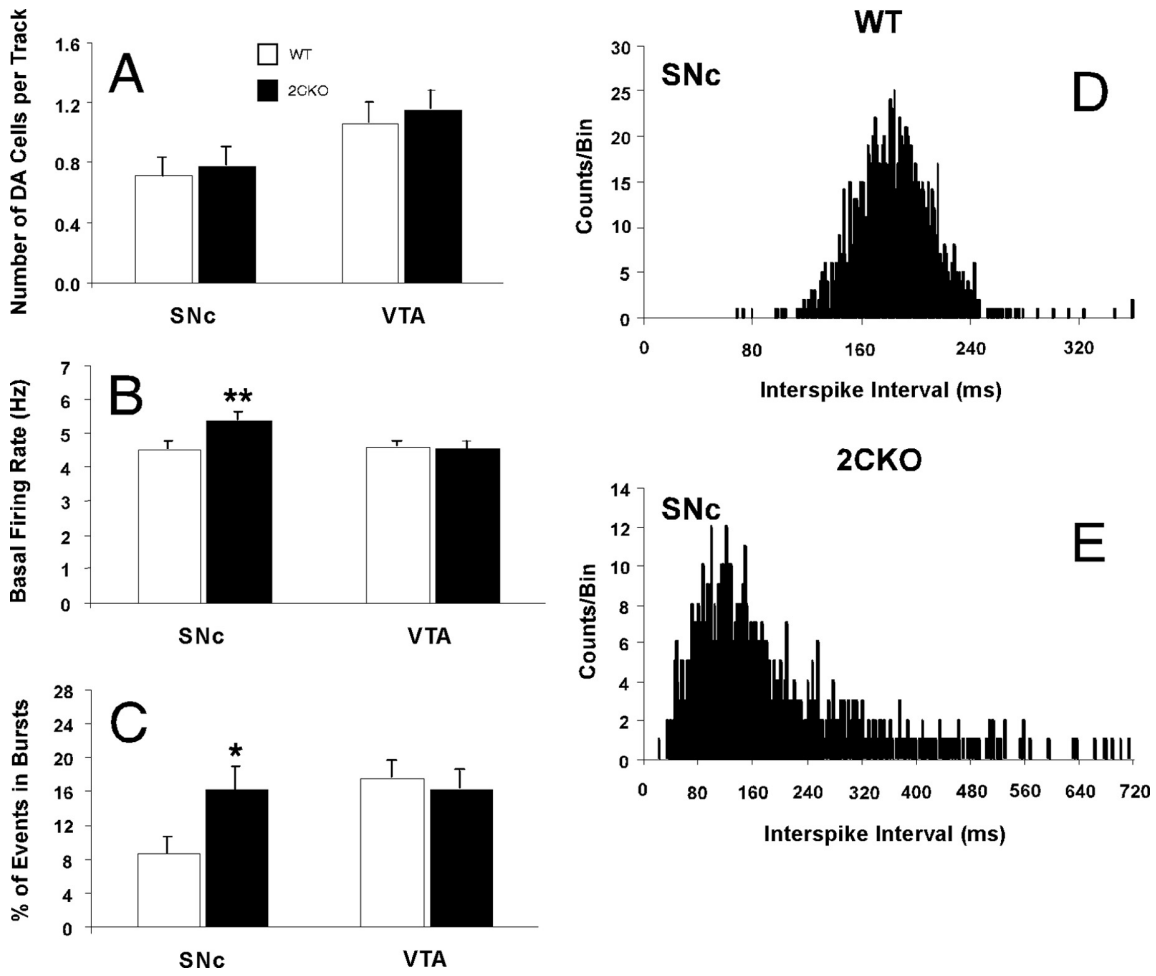

Figure 1. $5-\mathrm{HT}_{2} \mathrm{R}$ mutant mice display increased $\mathrm{SNc}$ dopaminergic neuronal activity. $\boldsymbol{A}$, Numbers of spontaneously active dopaminergic neurons encountered while recording from SNc and VTA revealed no phenotypic difference. $\boldsymbol{B}, 5-\mathrm{HT}_{2} \mathrm{R}$ mutant mice exhibit increased dopaminergic cell firing in SNc but not in VTA (5.38 \pm 0.23 vs $4.49 \pm 0.22$ spikes/s for SNc, $p<0.01$; $4.55 \pm 0.21$ vs $4.60 \pm 0.16$ spikes/s for VTA, NS). C, $5-\mathrm{HT}_{2 \mathrm{C}} \mathrm{R}$ mutant mice exhibit increased dopaminergic cell burst firing in SNc but not VTA ( $16.2 \pm 2.5 \%$ vs $8.6 \pm 1.9 \%$ cells bursting for SNc, $p<0.05 ; 16.6 \pm 2.5 \%$ vs $17.5 \pm 2 \%$ cells bursting for VTA, NS). $\boldsymbol{D}, \boldsymbol{E}$, Interspike interval histograms for $\mathrm{SNc}$ neurons recorded from wild-type $(\boldsymbol{D})$ and $5-\mathrm{HT}_{2} \mathrm{R}$ mutant $(\boldsymbol{E})$ mice demonstrate that SNc neurons from mutant mice have overall higher-frequency activity spike trains than those seen in wild-type mice. Data are represented as mean \pm SEM. $n=8$ per genotype. ${ }^{*} p<0.05 ;{ }^{* *} p<0.01$.

or direct radioligand binding. ${ }^{3} \mathrm{H}-\mathrm{SCH} 23390$ at $13.2 \mathrm{~nm}$ was used to assay for $\mathrm{D}_{1}$ receptors (run with an excess of cis-flupenthixol in the indirect reaction); ${ }^{3} \mathrm{H}-\mathrm{YM}-09151-2$ at $17 \mu \mathrm{M}$ was used to assay for $\mathrm{D}_{2}$ receptors (run with an excess of sulpiride in the indirect reaction). Following $1 \mathrm{~h}$ incubation on ice, sections were washed twice in chilled buffer, rinsed in chilled distilled water, and then gently dried with hot air. Sections were processed by investigators blinded to genotype and were stratified such that sections cut at similar levels were processed in the same batch. Slides were then placed in autoradiography cassettes reserved for tritium use, tritiated standards were placed with each film, and exposures were taken at $4^{\circ} \mathrm{C}$ for 4 weeks onto Kodak tritium hyperfilm. Films were developed by hand, scanned to computer, and analyzed using the public domain NIH Image program (developed at the United States National Institutes of Health and available at http://rsb.info.nih.gov/nih-image/). Landmarks for the DSt and NAc were taken from a standard mouse brain atlas (Paxinos and Franklin, 2001).

\section{Results}

SNc dopaminergic neurons display increased basal firing rates and bursting activity in $5-\mathrm{HT}_{2 \mathrm{C}} \mathrm{R}$ mutant mice

Extracellular microelectrode recordings were obtained to assess how the $h t r 2 c^{-}$mutation influenced baseline electrophysiological properties of midbrain dopaminergic neurons. No significant differences in the number of spontaneously active DA neurons were found between wild-type and mutant mice, either in the SNc or the VTA (Fig. 1A). At the SNc, statistically significant increases in dopaminergic neuron tonic firing rate (Fig. $1 B$ ) and percentage bursting activity (Fig. $1 C$ ) were noted in $5-\mathrm{HT}_{2 \mathrm{C}} \mathrm{R}$ mutant mice compared with wild types. Basal activity of SNc DA neurons in mutant mice increased by $20 \%$, whereas bursting ac- tivity of these neurons increased by almost $50 \%$. Interspike interval histograms revealed a skew toward lower-frequency activity in $5-\mathrm{HT}_{2 \mathrm{C}} \mathrm{R}$ mutant mice compared with wild types (Fig. $1 D, E$ ). This probably occurs as a result of the increased bursting behavior, leading to an increase in long interspike intervals between the bursts, although the mean frequency is increased. No statistically significant differences in either basal or percentage bursting activity were observed between $5-\mathrm{HT}_{2 \mathrm{C}} \mathrm{R}$ mutant and wild-type mice at the VTA (Fig. $1 B, C)$.

Extracellular dopamine is increased in the DSt and NAc of $5-\mathrm{HT}_{2 \mathrm{C}} \mathrm{R}$ mutant mice

To determine whether alterations in tonic and phasic SNc dopaminergic neuron activity were reflected at the dopaminergic terminal fields, we performed no net flux microdialysis to measure DSt and NAc baseline extracellular dopamine concentrations in awake, behaving mice. Estimates of extracellular DA concentrations in each brain region were calculated from the mean of three samples at each perfusate concentration $(0,5,10$, and $20 \mathrm{nM} \mathrm{DA})$. First-order regressions were used to obtain slope and intercept values, which were solved for the point of no net flux (zero intercept on the $y$-axis) (Parsons and Justice, 1994).

Figure 2, $A$ and $C$, depicts data where the microdialysis probe was placed within the DSt. DSt extracellular dopamine concentrations were nearly twice as large in mutant mice compared with wild types. Extracellular dopamine concentrations in the NAc were modestly increased in mutant mice compared with wild types (Fig. $2 B, C$ ).

\section{Increased syntactic grooming chain failures and altered} grooming behaviors in $5-\mathrm{HT}_{2 \mathrm{C}} \mathrm{R}$ mutant mice

Given the above electrophysiological and neurochemical evidence that $5-\mathrm{HT}_{2 \mathrm{C}} \mathrm{R}$ loss increases nigrostriatal dopaminergic activity, we proceeded to determine whether these changes were accompanied by altered DSt-organized behaviors. One such behavior is syntactic grooming. More than 15 min of overall grooming activity (pooled over the $10 \mathrm{~d}$ of observation) were obtained for all mice studied. In general, the majority of observed grooming behavior was nonsyntactic. The percentage of grooming activity occurring within syntactic chains (5\%, total observation) was similar to that reported by other groups (Aldridge and Berridge, 1998). No statistically significant phenotypic differences in syntactic grooming initiation rate, syntactic grooming frequency, or latency to first syntactic grooming episode were observed. However, $5-\mathrm{HT}_{2 \mathrm{C}} \mathrm{R}$ mutant mice spent significantly more time in syntactic phase 3 and significantly less time in syntactic phase 4 (Fig. 3A).

$5-\mathrm{HT}_{2 \mathrm{C}} \mathrm{R}$ mutant mice also demonstrated gross differences in nonsyntactic grooming behavior compared with wild-type mice (Fig. 3B). While there were no significant differences in overall grooming duration between wild-type and $5-\mathrm{HT}_{2 \mathrm{C}} \mathrm{R}$ mutant 

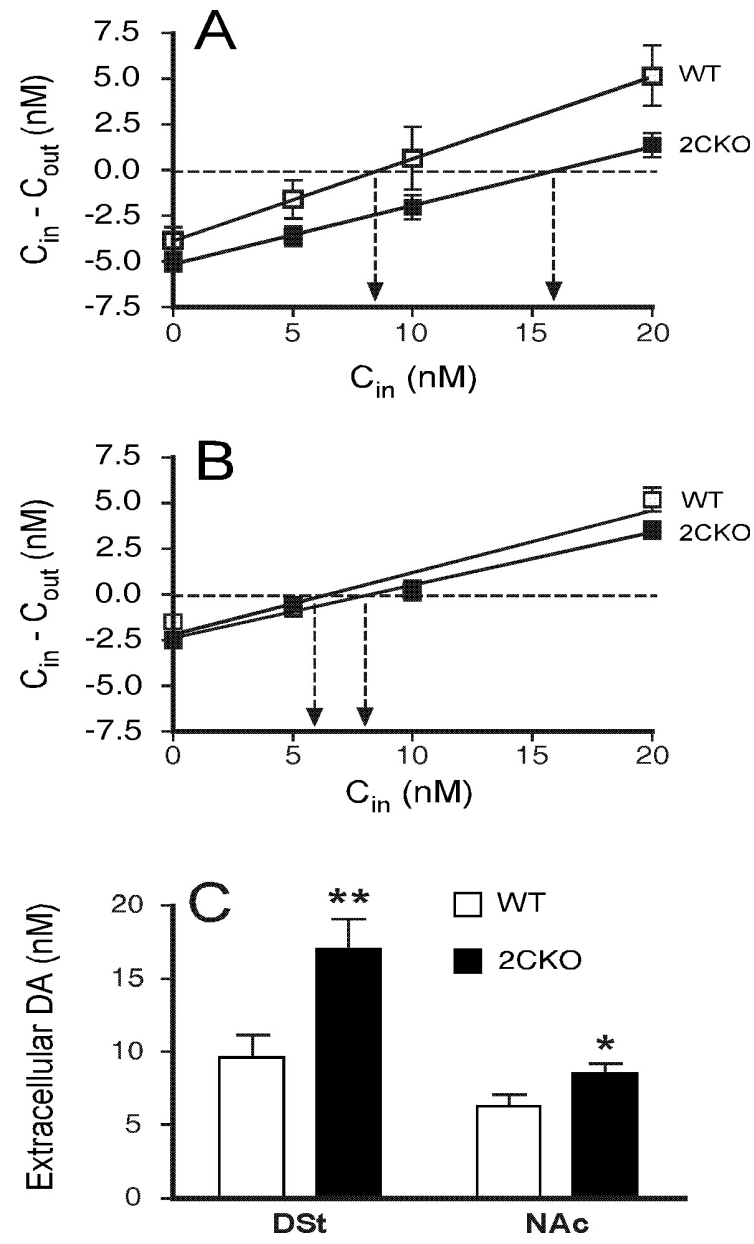

Figure 2. $5-\mathrm{HT}_{2} \mathrm{R}$ mutant mice display elevated striatal extracellular dopamine levels. $\boldsymbol{A}, \boldsymbol{B}$, No net flux plots in DSt $(\boldsymbol{A})$ and NAC $(\boldsymbol{B})$ of DA from $5-\mathrm{HT}_{2} \mathrm{R}$ mutant and wild-type mice. The $y$-axis indicates DA concentration differences between aCSF entering the probe $\left(C_{i n}\right)$ and aCSF exiting the probe $\left(C_{\text {out }}\right)$. The point of no net flux ( $y=0 \mathrm{~nm}$; horizontal dotted line) corresponds to DA equilibrium between tissue and microdialysis probe revealing extracellular DA concentration (arrows). Estimates of in vivo DA recovery in the DSt, as indicated by the slope of the no net flux curve, did not differ between $5-\mathrm{HT}_{2} \mathrm{R}$ mutant mice $(0.32 \pm 0.03)$ and wild types $(0.45 \pm$ $0.07, F_{(1,14)}=3.537$, NS). Similarly, estimates of in vivo DA recovery in the NAc did not differ between groups $\left(5-\mathrm{HT}_{2 C} \mathrm{R}\right.$ mutant mice, $0.29 \pm 0.04$; wild types, $0.34 \pm 0.03, F_{(1,14)}=0.881$, NS). C, $5-\mathrm{HT}_{2 C} \mathrm{R}$ mutant mice display elevated mean basal dopamine concentration in the DSt $\left(17 \pm 2.1 \mathrm{~nm}\right.$ vs $9.6 \pm 1.6 \mathrm{~nm}$ in wild types, $\left.F_{(1,15)}=8.924, p<0.01\right)$ and NAc $(8.5 \pm 0.7 \mathrm{~nm}$ vs $6.3 \pm 0.8 \mathrm{~nm}$ in wild types, $\left.F_{(1,15)}=4.887, p<0.05\right)$. Data are represented as mean \pm SEM. $n=8$ per genotype. ${ }^{*} p<0.05$; ${ }^{* *} p<0.01$.

mice, $5-\mathrm{HT}_{2 \mathrm{C}} \mathrm{R}$ mutant mice had a significantly higher nonsyntactic grooming initiation rate and a correspondingly significant decrease in nonsyntactic grooming episode duration. No differences in latency to nonsyntactic grooming episodes were noted.

\section{$5-\mathrm{HT}_{2 \mathrm{C}} \mathrm{R}$ mutant mice perform more orofacial motor} stereotypies following $\mathrm{D}$-amphetamine treatment

We evaluated LA and stereotypy responses to D-amphetamine treatment in wild-type and $5-\mathrm{HT}_{2 \mathrm{C}} \mathrm{R}$ mutant mice. LA in response to $2.5,5$, and $10 \mathrm{mg} / \mathrm{kg}$ D-amphetamine is depicted in Figure $4 A-C$. Characteristic dose- and time-dependent locomotor responses to D-amphetamine were observed. A $2.5 \mathrm{mg} / \mathrm{kg}$ dose of $\mathrm{D}$-amphetamine resulted in a robust locomotor response that reached peak values at $40 \mathrm{~min}$, then declined, reaching control values at $110 \mathrm{~min}$ after injection (Fig. $4 A$ ). After $5 \mathrm{mg} / \mathrm{kg}$ $\mathrm{D}$-amphetamine, locomotion increased more rapidly, peaking 30 min after injection, declining at a slower rate, and finally attaining baseline values $180 \mathrm{~min}$ after injection (Fig. 4B). An early but smaller peak in locomotion ( $10 \mathrm{~min}$ after injection) was observed after $10 \mathrm{mg} / \mathrm{kg}$ dose of D-amphetamine, but locomotion was rapidly suppressed, remaining at minimal levels until 110-120 min after injection, followed by another rise in locomotion lasting until $>210$ min after injection (Fig. 4C). Overall, 5-HT $2 \mathrm{C}$ mutant mice showed less LA response to D-amphetamine.

The transient decrease in D-amphetamine-induced LA has been proposed to result from an increase in focused stereotypies (Yates et al., 2007). Our data indicate that the expression of these stereotypies may be enhanced in $5-\mathrm{HT}_{2 \mathrm{C}} \mathrm{R}$ mutant mice. To test this hypothesis, we measured motor stereotypy in response to $2.5,5$, and $10 \mathrm{mg} / \mathrm{kg} \mathrm{D}$-amphetamine in wild-type and $5-\mathrm{HT}_{2 \mathrm{C}} \mathrm{R}$ mutant mice. After $2.5 \mathrm{mg} / \mathrm{kg}$ D-amphetamine, there were no significant phenotypic differences in stereotypic activity (Fig. 4D). However, detailed analysis of stereotypic behaviors revealed that $5-\mathrm{HT}_{2 \mathrm{C}} \mathrm{R} \mathrm{mu}-$ tant mice spent significantly more time in rearing and jumping (supplemental Fig. 1, available at www.jneurosci.org as supplemental material). Following $5 \mathrm{mg} / \mathrm{kg}$ D-amphetamine, $5-\mathrm{HT}_{2 \mathrm{C}} \mathrm{R}$ mutant mice spent significantly more time in total stereotypy than did wild type (Fig. $4 E$ ). At the highest dose of $10 \mathrm{mg} / \mathrm{kg}$, mice were almost fully engaged in orofacial stereotypy, but there was no significant phenotypic difference (Fig. $4 F$ ).

\section{5- $\mathrm{HT}_{2 \mathrm{C}} \mathrm{R}$ mutant mice demonstrate increased stereotypic behaviors following selective DAT blockade}

We then examined stereotypic behavioral responses to the selective DAT antagonist GBR 12909 (Heikkila and Manzino, 1984 ) in $5-\mathrm{HT}_{2 \mathrm{C}} \mathrm{R}$ mutant and wild-type mice. We used a modified Creese-Iversen scale to score stereotyped behaviors in wild-type and $5-\mathrm{HT}_{2 \mathrm{C}} \mathrm{R}$ mutant mice treated with GBR 12909 (Fig. 5A). We also examined the impact of $5-\mathrm{HT}_{2 \mathrm{C}} \mathrm{R}$ pharmacological blockade (using SB 206553) on stereotypic behavioral responses to GBR 12909 (Fig. 5B). 5- $\mathrm{HT}_{2 \mathrm{C}} \mathrm{R}$ mutant mice displayed increased stereotypic behaviors in response to intermediate doses of GBR 12909. Similarly, mice receiving both SB 206553 and intermediate doses of GBR 12909 displayed greater stereotypic behaviors compared with wild-type mice receiving GBR 12909.

\section{No phenotypic difference in striatal DA release after D- amphetamine or selective DAT blockade}

Given the phenotypic differences we observed in locomotor activity and stereotypy following psychostimulant administration, we hypothesized that we would find phenotypic differences in psychostimulant-evoked DSt dopamine extracellular concentrations. We examined dopamine release in the DSt of $5-\mathrm{HT}_{2 \mathrm{C}} \mathrm{R} \mathrm{mu}$ tant and wild-type mice in response to 2.5 and $5 \mathrm{mg} / \mathrm{kg}$ D-amphetamine (Fig. 6A,B). A dose of $2.5 \mathrm{mg} / \mathrm{kg}$ D-amphetamine induced a sharp increase in DA release, which peaked $40 \mathrm{~min}$ after the injection $(883.7 \pm 114.13$ and $731 \pm 92.7 \%$ increase for wildtype and $5-\mathrm{HT}_{2 \mathrm{C}} \mathrm{R}$ mutant mice respectively, NS). Similarly, a 5 $\mathrm{mg} / \mathrm{kg} \mathrm{D}$-amphetamine dose induced a sharp increase in DA release, which peaked $40 \mathrm{~min}$ after injection (1072.35 \pm 140.3 and $1242.6 \pm 190.7 \%$ increases in wild-type and $5-\mathrm{HT}_{2 \mathrm{C}} \mathrm{R}$ mutant mice respectively, NS). However, neither genotype nor any of its relevant interactions were found to be significant by repeatedmeasures ANOVA. Thus, we were unable to detect any phenotypic differences in D-amphetamine-evoked DSt extracellular dopamine concentrations.

We then examined dopamine release in the DSt of $5-\mathrm{HT}_{2 \mathrm{C}} \mathrm{R}$ mutant and wild-type mice in response to 3 and $10 \mathrm{mg} / \mathrm{kg} \mathrm{GBR}$ 


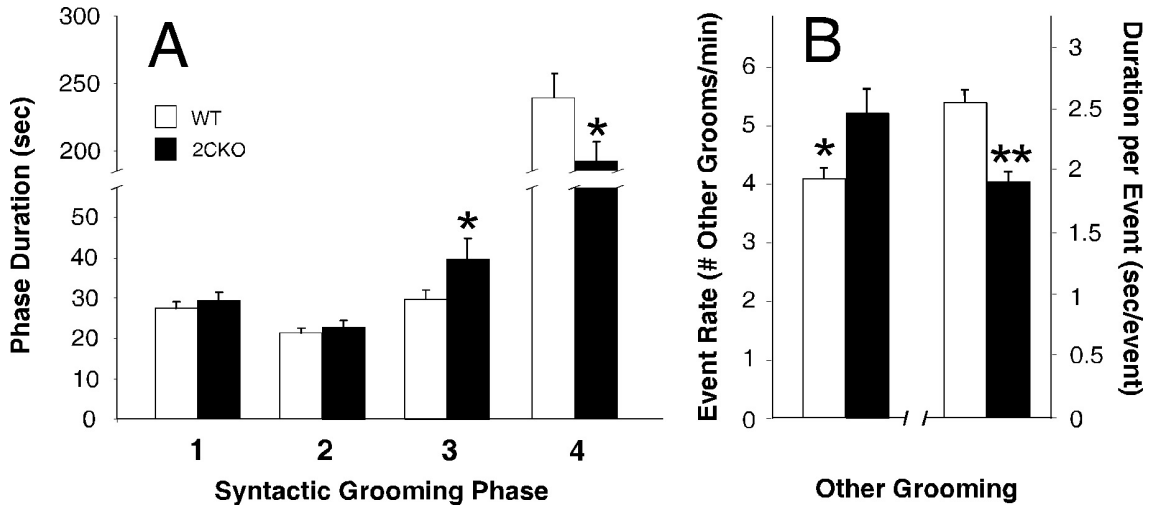

Figure 3. $\quad 5-\mathrm{HT}_{2} \mathrm{R}$ mutant mice exhibit altered syntactic grooming chains. $\boldsymbol{A}$, Increased duration of phase 3 and decreased duration of phase 4 syntactic grooming in $5-\mathrm{HT}_{2} \mathrm{R}$ mutant mice. Mean phase 3 duration was $29.8 \pm 2.2 \mathrm{~s}$ in wild-type mice, $39.8 \pm 5$ s in $5-\mathrm{HT}_{2} \mathrm{R}$ mutant mice $(p<0.05)$; mean phase 4 duration was $239.2 \pm 17.9$ s in wild-type mice, $192.0 \pm 14.2 \mathrm{~s}$ in $5-\mathrm{HT}_{2 C} \mathrm{R}$ mutant mice $(p<0.03)$. $B$, Alteration of nonsyntactic grooming properties in $5-\mathrm{HT}_{2} \mathrm{R}$ mutant mice. $5-\mathrm{HT}_{2 C} \mathrm{R}$ mutant mice exhibit increased nonsyntactic grooming event initiation ( $5.20 \pm 0.4$ grooming events per minute vs $4.07 \pm 0.16$ in wild types; $p<0.015$ ) and reduced nonsyntactic grooming duration ( $1.89 \pm 0.1$ vs $2.55 \pm 0.11$ sin wild types, $p<0.0007$ ). Data are represented as mean \pm SEM. $n=8$ per genotype. ${ }^{*} p<0.05 ;{ }^{* *} p<0.001$.

12909 administration (Fig. 6C,D). We observed an overall increase in DSt extracellular dopamine concentration following drug administration. However, neither genotype nor any genotype interactions were found to be significant by repeatedmeasures ANOVA. Thus, we observe that differences in locomotor and stereotypical behavior following psychostimulant administration are not accompanied by phenotypic differences in DSt extracellular dopamine concentrations.

\section{5- $\mathrm{HT}_{2 \mathrm{C}} \mathrm{R}$ mutant mice display enhanced $\mathrm{D}_{1}$ receptor agonist-induced stereotypy}

The above findings suggest that $5-\mathrm{HT}_{2 \mathrm{C}} \mathrm{Rs}$ influence behavioral responses to dopamine release. This raises the possibility that $5-\mathrm{HT}_{2 \mathrm{C}} \mathrm{R}$ mutant mice have enhanced behavioral responses to DA receptor activation. Figure 7 displays LA in response to 10 $\mathrm{mg} / \mathrm{kg}$ injection of the $\mathrm{D}_{1}$ receptor agonist SKF 81297 . SKF 81297 increased LA in both wild-type and $5-\mathrm{HT}_{2 \mathrm{C}} \mathrm{R}$ mutant mice relative to saline-injected controls. However, the magnitude of the increase was diminished in $5-\mathrm{HT}_{2 \mathrm{C}} \mathrm{R}$ mutant mice. Stereotypy observed during these trials was mainly orofacial in nature, with $5-\mathrm{HT}_{2 \mathrm{C}} \mathrm{R}$ mutant mice displaying a robust enhancement of stereotypy relative to the wild-type mice (mutant mice spent $86.91 \pm 6.92 \%$ time in focused stereotypy compared with $21.29 \pm 6.18$ for wild-type mice, $\left.F_{(1,6)}=49.98, p<0.001\right)$. We further examined the effect of quinpirole $(0.6,2$, and $6 \mathrm{mg} / \mathrm{kg}$ ) on LA and stereotypy. Quinpirole treatment evoked no phenotypic effects on LA or stereotypy.

\footnotetext{
Absence of phenotypic difference in striatal $D_{1}$ and $D_{2}$ receptor binding

The enhanced responses of 5- $\mathrm{HT}_{2 \mathrm{C}} \mathrm{R}$ mutant mice to $\mathrm{D}_{1}$ receptor stimulation may reflect a phenotypic difference in $\mathrm{D}_{1}$ receptor expression. To test this hypothesis, ${ }^{3} \mathrm{H}$ receptor-ligand-binding autoradiography was used to assess $D_{1}$ and $D_{2}$ receptor binding in DSt and NAc. No phenotypic differences in receptor binding in DSt and NAc were observed in either of these regions when comparing wild-type to $5-\mathrm{HT}_{2 \mathrm{C}} \mathrm{R}$ mutant mice (supplemental Fig. 2, available at www.jneurosci.org as supplemental material).
}

Absence of phenotypic difference in $D_{1}$ receptor activation of DSt MSNs

Brain slices were used to examine the firing properties of DSt MSNs. Neurons were brought to approximately $-80 \mathrm{mV}$ by passage of DC current via the patch amplifier, and then a series of $300 \mathrm{~ms}$ current pulses was delivered every $30 \mathrm{~s}$. Dopamine, acting via the $D_{1}$ receptor, can enhance action potential firing in the DSt (Surmeier et al., 1995; Hernández-López et al., 1997). In agreement, the selective $\mathrm{D}_{1}$ receptor agonist SKF 81297 dose-dependently enhanced firing in wild-type and $5-\mathrm{HT}_{2 \mathrm{C}} \mathrm{R}$ mutant mice, with significant enhancement of action potential generation at 10 $\mu \mathrm{M}$ (supplemental Fig. 3A, available at www.jneurosci.org as supplemental material) but not $3 \mu \mathrm{M}$ (supplemental Fig. 3C, available at www.jneurosci.org as supplemental material). However, there were no phenotypic differences in firing enhancement. SKF 81297 did not alter the input resistance, measured using a $33.3 \mathrm{pA}$ hyperpolarizing pulse, suggesting that there was no effect of $D_{1}$ receptor activation on inwardly rectifying potassium channels (supplemental Fig. $3 B, D$, available at www.jneurosci.org as supplemental material). Finally, as shown in supplemental Table 1 (available at www.jneurosci.org as supplemental material), there were no differences in a number of basic firing parameters related to action potential waveform and input resistance $(n=14$ cells from six wild-type mice, $n=14$ cells from five $5-\mathrm{HT}_{2 \mathrm{C}} \mathrm{R}$ mice), suggesting that $5-\mathrm{HT}_{2 \mathrm{C}} \mathrm{R}$ deletion did not alter the basal function of several channels active during firing.

\section{Discussion}

These studies suggest that $5-\mathrm{HT}_{2 \mathrm{C}} \mathrm{Rs}$ have a significant role in controlling nigrostriatal physiology and behavior. We demonstrate that $5-\mathrm{HT}_{2 \mathrm{C}} \mathrm{R}$ loss increases $\mathrm{SNc}$ dopaminergic neuron firing rates and DSt extracellular dopamine concentrations and enhances behaviors associated with DSt activation. Loss of 5- $\mathrm{HT}_{2 \mathrm{C}} \mathrm{R}$ function enhances psychostimulant-induced stereotypy. This enhancement occurs without phenotypic differences in the elevation of psychostimulant-induced striatal extracellular dopamine concentrations. Thus, loss of $5-\mathrm{HT}_{2 \mathrm{C}} \mathrm{R}$ function may be accompanied by enhanced behavioral responses to released dopamine. Phenotypic differences in stereotypic behavior following selective $\mathrm{D}_{1}$ receptor agonist stimulation support this hypothesis. These differences were not attributable to increases in DSt $D_{1}$ receptor expression or MSN response to dopaminergic stimulation. Thus, these findings suggest that $5-\mathrm{HT}_{2 \mathrm{C}} \mathrm{Rs}$ inhibit behaviors associated with nigrostriatal function at multiple loci.

\section{5- $\mathrm{HT}_{2 \mathrm{C}} \mathrm{R}$ loss evokes a tonic activation of nigrostriatal dopaminergic neurotransmission}

In mice lacking 5- $\mathrm{HT}_{2 \mathrm{C}} \mathrm{Rs}$, $\mathrm{SNc}$ dopaminergic neurons displayed elevated tonic firing rates and an increased percentage of burstfiring cells. 5- $\mathrm{HT}_{2 \mathrm{C}} \mathrm{Rs}$ are expressed on GABAergic neuronal subpopulations (Di Giovanni et al., 2001) of the SNc [by in situ hybridization (Eberle-Wang et al., 1997)] and VTA [by immunocytochemistry (Bubar and Cunningham, 2007)]. Thus, loss of $5-\mathrm{HT}_{2 \mathrm{C}} \mathrm{R}$-evoked activity within these GABAergic cells could diminish inhibitory drive onto SNc neurons. This is consistent with 
pharmacological studies suggesting that $5-\mathrm{HT}_{2 \mathrm{C}} \mathrm{Rs}$ suppress $\mathrm{SNc}$ neuronal firing [Di Giovanni et al. (1999) and Porras et al. (2002), using SB-206553] and burst firing [Blackburn et al. (2006), using SB-200646A].

Surprisingly, our data demonstrate that the $h t r 2 c^{-}$null mutation has a greater impact on SNc cell firing rate and bursting properties than on those of VTA dopaminergic neurons. Previous studies clearly demonstrate that pharmacological $5-\mathrm{HT}_{2 \mathrm{C}} \mathrm{R}$ activation/inhibition evokes a corresponding inhibition/activation of VTA neuronal firing (Di Giovanni et al., 1999, 2000; Di Matteo et al., 1999, 2000); (for review, see Giorgetti and Tecott, 2004). Many of these studies suggest that systemic modulation of $5-\mathrm{HT}_{2 \mathrm{C}} \mathrm{R}$ activity alters VTA neuronal activity to a greater extent than SNc neuronal activity (Di Matteo et al., 2001, 2002a; Blackburn et al., 2002). However, a number of factors complicate this interpretation. Studies that use different $5-\mathrm{HT}_{2 \mathrm{C}} \mathrm{R}$ antagonists have yielded disparate results. For example, previous reports suggest that $5-\mathrm{HT}_{2 \mathrm{C}} \mathrm{R}$ antagonism increases (Di Giovanni et al., 1999) or has no effect on (Di Matteo et al., 1999) SNc dopaminergic neuronal firing rates. Some of these issues may relate to differences in the extent to which antagonist compounds block $5-\mathrm{HT}_{2 \mathrm{C}} \mathrm{R}$ constitutive activity (De Deurwaerdère et al., 2004).

Increases in SNc neuron firing rate and bursting were accompanied by increases in extracellular DSt dopamine concentration as determined by no net flux methods. This finding is also concordant with previous studies demonstrating increased striatal dopamine concentrations following treatment with $5-\mathrm{HT}_{2 \mathrm{C}} \mathrm{R}$ antagonists (Navailles et al., 2004). Conversely, extracellular striatal dopamine concentrations were decreased after systemic $5-\mathrm{HT}_{2 \mathrm{C}} \mathrm{R}$ agonism (Di Matteo et al., 2004). Moreover, constitutive $5-\mathrm{HT}_{2 \mathrm{C}} \mathrm{R}$ activity in absence of bound ligand has been proposed to decrease striatal dopamine concentrations (De Deurwaerdère et al., 2004).

In accord with the observed changes in baseline SNc neuronal firing properties and DSt extracellular DA concentrations, we observed altered grooming behavior in $5-\mathrm{HT}_{2 \mathrm{C}} \mathrm{R}$ mutant mice. Increases in total grooming have previously been observed following treatment with dopamine $\mathrm{D}_{1}$ receptor agonists (Berridge and Aldridge, 2000 ) and in mice expressing a hypoactive dopamine reuptake transporter (Berridge et al., 2005). Like 5- $\mathrm{HT}_{2 \mathrm{C}} \mathrm{R}$ mutant mice, the dopamine reuptake transporter hypomorphic mice displayed elevated nonsyntactic grooming event rates. $5-\mathrm{HT}_{2 \mathrm{C}} \mathrm{R}$ mutant mice also demonstrate a dysregulation of syntactic grooming, a behavior spe-
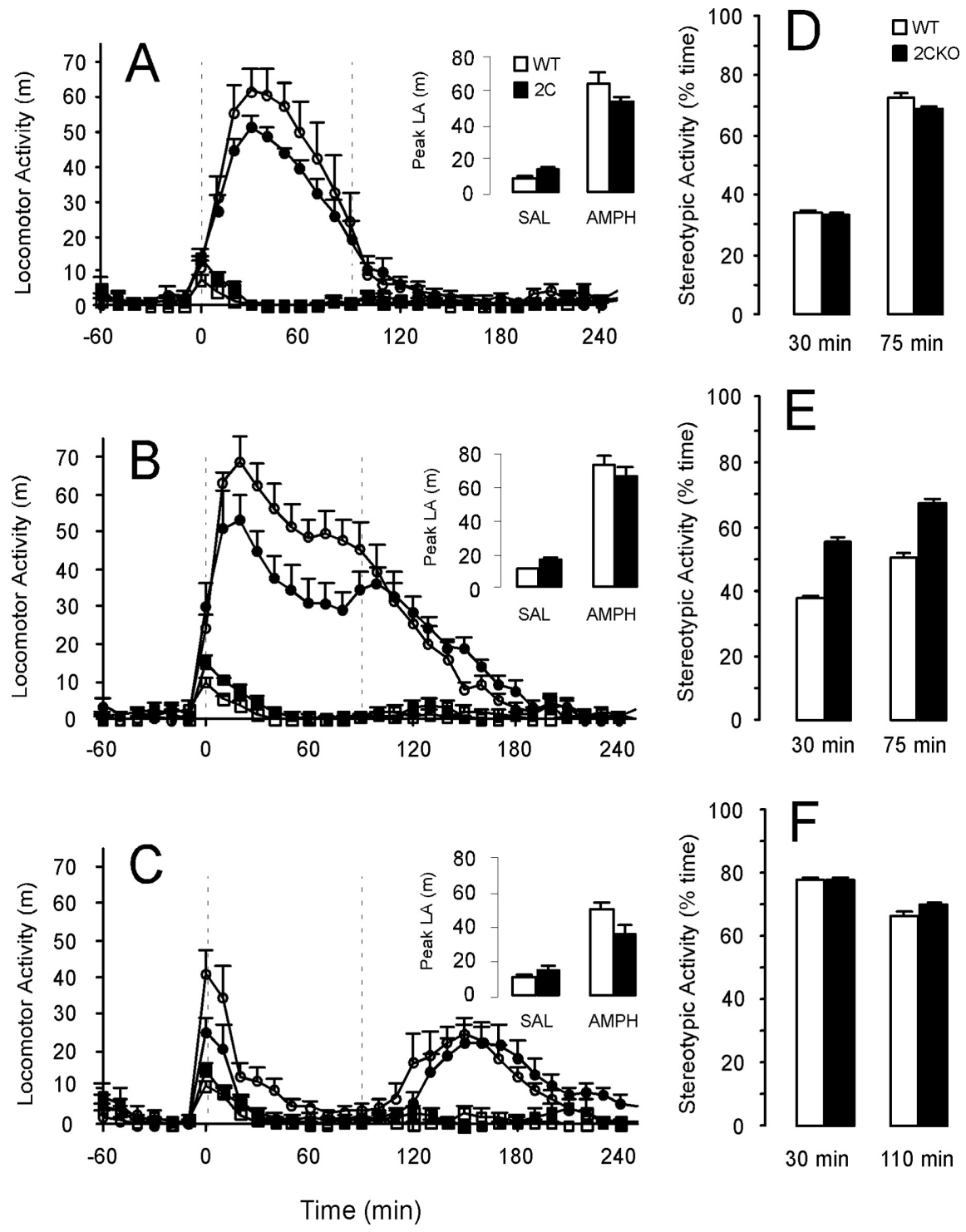

Figure 4. $\quad 5-\mathrm{HT}_{2 C} \mathrm{R}$ mutant mice display altered motor responses to $\mathrm{D}$-amphetamine. $\bigcirc$, D-Amphetamine-treated wild-type mice; , D-amphetamine-treated $5-\mathrm{HT}_{2} \mathrm{R}$ mutant mice; $\square$, saline-treated wild-type mice; $\square$, saline-treated $5-\mathrm{HT}_{2} \mathrm{R}_{\mathrm{R}}$ mutant mice. $\boldsymbol{A}$, Locomotor activity following $2.5 \mathrm{mg} / \mathrm{kg} \mathrm{D}$-amphetamine. Repeated-measures ANOVA on locomotor distance traveled between 0 and 90 min after injection revealed significant effects of treatment $\left(F_{(1,27)}=131.14 ; p<0.001\right)$ and treatment $\times$ time interaction $\left(F_{(1,27)}=11.69 ; p<0.01\right)$. Inset, ANOVA conducted on peak activity showed significant effects of treatment $\left(F_{(1,26)}=175.69 ; p<0.001\right)$ and treatment $\times$ genotype interaction $\left(F_{(1,26)}=5.79 ; p<0.05\right)$. B, Locomotor activity following $5 \mathrm{mg} / \mathrm{kg}$ D-amphetamine. Repeated-measures ANOVA on locomotor distance traveled between 0 and 90 min after injection revealed significant effects of time $\left(F_{(1,26)}=9.24 ; p<0.01\right)$, treatment $\left(F_{(1,26)}=301.19 ; p<0.001\right)$, and treatment $\times$ genotype interaction $\left(F_{(1,26)}=6.94 ; p<0.05\right)$. Inset, ANOVA conducted on peak activity showed a significant effect of treatment $\left(F_{(1,26)}=196.26 ; p<0.001\right)$. C, Locomotor activity following $10 \mathrm{mg} / \mathrm{kg}$ D-amphetamine. Repeated-measures ANOVA on loc0motor distance traveled between 0 and 90 min after injection showed significant effects of genotype $\left(F_{(1,26)}=6.04, p<0.05\right)$, treatment $\left(F_{(1,26)}=41.31, p<0.001\right)$, and time $\left(F_{(1,26)}=215.61, p<0.001\right)$, as well as interactions of time $\times$ genotype $\left(F_{(1,26)}\right.$ $=4.93 ; p<0.05)$, treatment $\times$ genotype $\left(F_{(1,26)}=12.85 ; p<0.01\right)$, and time $\times$ treatment $\left(F_{(1,26)}=47.82 ; p<0.001\right)$. The tertiary interaction of time $\times$ treatment $\times$ genotype was also significant $\left(F_{(1,26)}=10.25 ; p<0.01\right)$. Inset, ANOVA conducted on peak activity showed significant effects of treatment $\left(F_{(1,26)}=63.44 ; p<0.001\right)$ and treatment $\times$ genotype $\left(F_{(1,26)}=5.76 ; p<\right.$ $0.05)$. $D$, Repeated-measures ANOVA conducted on percentage time spent in stereotypy following $2.5 \mathrm{mg} / \mathrm{kg} D$-amphetamine revealed no significant phenotypic differences. $\boldsymbol{E}, 5-\mathrm{HT}_{2} \mathrm{R}$ mutant mice display greater focused stereotypy following $5 \mathrm{mg} / \mathrm{kg}$ D-amphetamine $\left(F_{(1,11)}=5.14, p<0.05\right)$. $\boldsymbol{F}$, No phenotypic difference in focused stereotypy following $10 \mathrm{mg} / \mathrm{kg}$ D-amphetamine. Data are represented as mean \pm SEM. $n=7-8$ per genotype per treatment.

cifically linked to DSt function (Cromwell and Berridge, 1996; Aldridge and Berridge, 1998; Aldridge et al., 2004). Similar to what is observed following $\mathrm{D}_{1}$ receptor agonist treatment, $5-\mathrm{HT}_{2 \mathrm{C}} \mathrm{R}$ mutant mice spend less time in the final phase (phase 4) of syntactic grooming chains compared with wild-type mice (Matell et al., 2006). Al- 

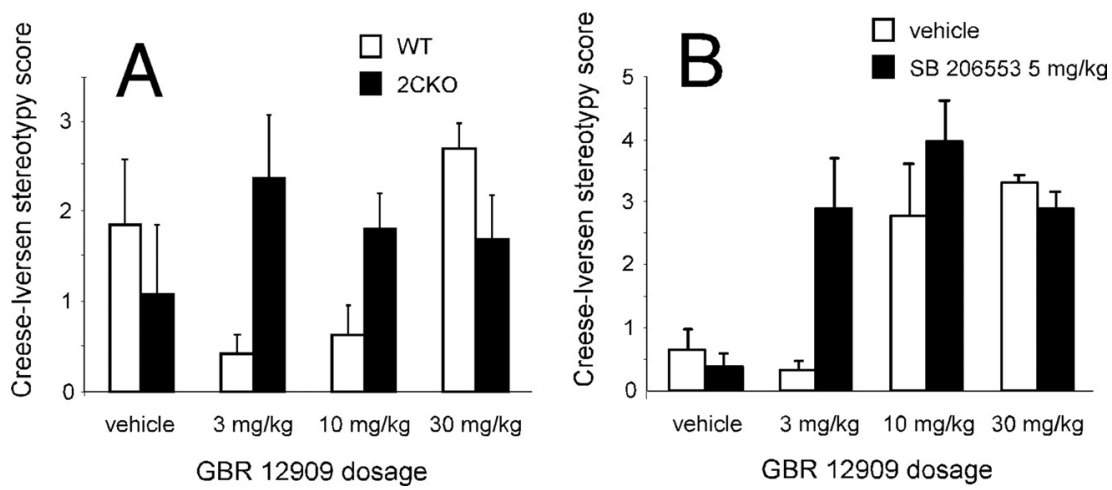

Figure 5. Enhanced sensitivity of $5-\mathrm{HT}_{2} \mathrm{R}$ mutant mice to induction of motor stereotypy by dopamine reuptake blockade. $A$, Increased GBR 12909-evoked stereotypy observed in 5- $\mathrm{HT}_{2 \mathrm{C}} \mathrm{R}$ mutant mice compared with wild types $\left(F_{(3,56)}=4.017, p<0.012\right.$ for genotype $X$ dose interaction). Behavior evaluated $90 \mathrm{~min}$ after drug administration. $\boldsymbol{B}$, Increased GBR 12909-evoked stereotypy observed in $C 57 \mathrm{BL} / 6 \mathrm{~J}$ mice following treatment with the $5-\mathrm{HT}_{2} \mathrm{R}$ inverse agonist $\mathrm{SB} 206553\left(F_{(3,55)}=3.764, p<0.016\right.$ for SB $206553 \times$ GBR 12909 dose interaction). In animals receiving both GBR 12909 and SB 206553, drugs were administered simultaneously. Behavior evaluated $90 \mathrm{~min}$ after drug administration. Data are represented as mean \pm SEM. $n=7$ per genotype per treatment.
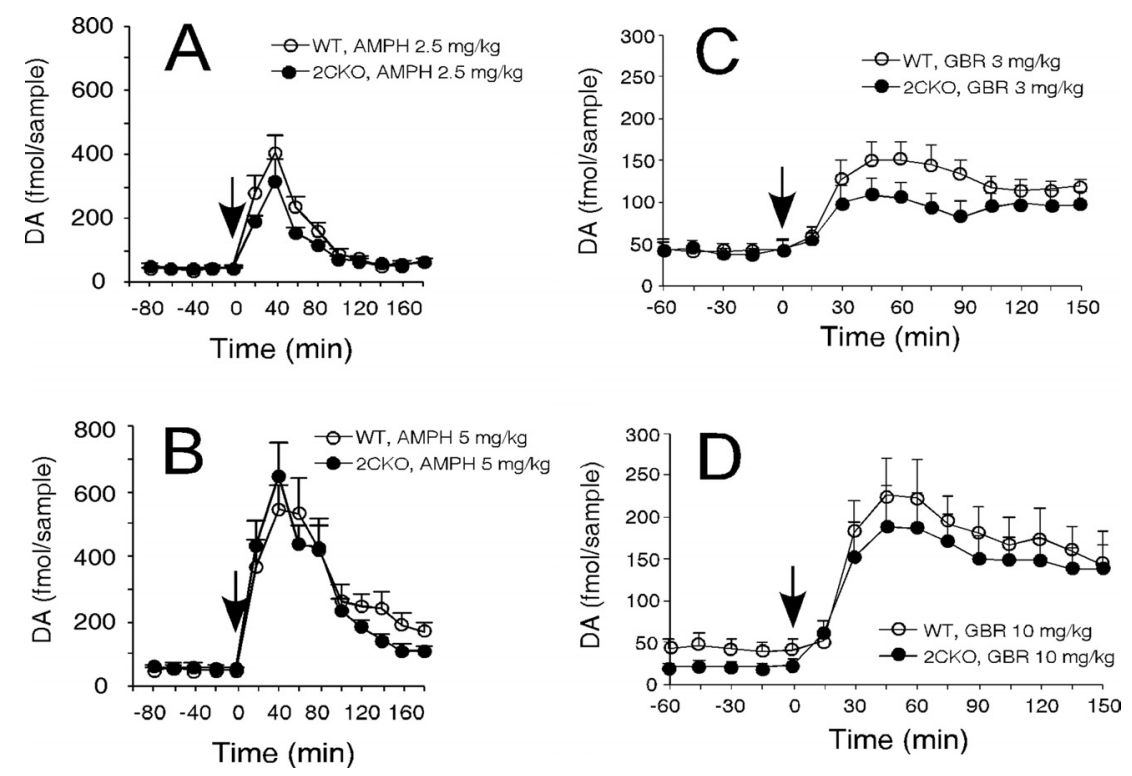

Figure 6. No phenotypic effect on DSt extracellular dopamine concentrations after treatment with D-amphetamine or GBR 12909. $\bigcirc$, Wild-type mice;, $5-\mathrm{HT}_{2} \mathrm{R}$ mutant mice. $\boldsymbol{A}-\boldsymbol{D}$, DSt extracellular dopamine following D-amphetamine $2.5 \mathrm{mg} / \mathrm{kg}(\boldsymbol{A})$, D-amphetamine $5 \mathrm{mg} / \mathrm{kg}(\boldsymbol{B})$, GBR $129093 \mathrm{mg} / \mathrm{kg}(\boldsymbol{C})$, and GBR $1290910 \mathrm{mg} / \mathrm{kg}(\boldsymbol{D})$. For $\boldsymbol{A}-\boldsymbol{D}$, no phenotypic differences were noted between drug- and vehicle-treated groups. Arrows indicate the time of drug administration. Data are represented as mean \pm SEM. $n=5-8$ per genotype per treatment.

though these findings are consistent with an enhancement of nigrostriatal dopamine system activity, it is also possible that the absence of $5-\mathrm{HT}_{2 \mathrm{C}} \mathrm{Rs}$ from basal ganglia structures could contribute to the observed grooming phenotypes.

\section{5- $\mathrm{HT}_{2 \mathrm{C}} \mathrm{R}$ loss enhances psychostimulant-induced motor activity}

Both locomotor stereotypies and focused stereotypies (such as grooming and gnawing) are prominent behaviors associated with psychostimulants. Typically, locomotor stereotypic behaviors are observed at lower psychostimulant doses, while focused stereotypies predominate with higher psychostimulant doses. In $5-\mathrm{HT}_{2 \mathrm{C}} \mathrm{R} \mathrm{mu}-$ tant mice, focused stereotypies were the prevalent behavior following D-amphetamine treatment. In contrast, locomotor stereotypies were more prevalent in wild-type mice except at the highest tested $\mathrm{D}$-amphetamine dosage. In mutant mice, behavioral responses were characterized by greater duration of focused stereotypy and greater sensitivity to focused stereotypy. Because D-amphetamine nonspecifically influences monoamine release and uptake, we examined the consequences of selective DA transporter blockade using GBR 12909. Similarly, focused stereotypies were observed more frequently in $5-\mathrm{HT}_{2 \mathrm{C}} \mathrm{R}$ mutant mice than in wild-type littermates following GBR 12909 treatment.

Unexpectedly, we did not observe phenotypic differences in DSt extracellular dopamine concentrations following administration of either GBR 12909 or D-amphetamine. Nevertheless, we observed enhanced focused stereotypies in $5-\mathrm{HT}_{2 \mathrm{C}} \mathrm{R}$ mutant mice. The finding of phenotypic differences in psychostimulant-evoked nigrostriatal behaviors in the absence of differences in nigrostriatal extracellular dopamine concentration raised the possibility that behavioral responses to released dopamine are enhanced by the $h t r 2 c^{-}$mutation.

\section{5-HT ${ }_{2 \mathrm{C}} \mathrm{R}$ loss enhances behavioral sensitivity to $D_{1}$ receptor activation} Phenotypic differences in the response to dopamine release could occur through changes within signaling pathways activated by $\mathrm{D}_{1}$-like and/or $\mathrm{D}_{2}$-like receptors. $5-\mathrm{HT}_{2 \mathrm{C}} \mathrm{R}$ mutant mice demonstrated enhanced sensitivity to the behavioral effects of the $D_{1}$ receptor agonist SKF 81297, while no phenotypic differences were noted in behavioral responses to the $\mathrm{D}_{2}$ receptor agonist quinpirole. Thus, $\mathrm{D}_{1}$ receptor signaling pathways may contribute substantially to the enhanced behavioral responses of $5-\mathrm{HT}_{2 \mathrm{C}} \mathrm{R}$ mutant mice to psychostimulants.

In light of these findings and the known expression of $5-\mathrm{HT}_{2 \mathrm{C}} \mathrm{Rs}$ within the DSt (Alex et al., 2005), we evaluated $\mathrm{D}_{1}$ receptor expression and function in wild-type and mutant mice. We found no phenotypic difference in DSt $D_{1}$ receptor expression by autoradiography. We then examined DSt MSN responses to $\mathrm{D}_{1}$ receptor stimulation. Electrophysiological studies revealed enhancement of firing after $D_{1}$ receptor activation, as has been described (Hernández-López et al., 1997). However, no significant phenotypic differences in the $D_{1}$ receptor firing enhancement were noted. Additionally, we did not observe gross phenotypic differences in MSN action potential waveform or other basic parameters. Thus, we did not detect significant phenotypic differences in intrinsic striatal function.

Within the basal ganglia, information from the "direct" [consisting of striatal to substantia nigra reticulata/globus pallidus interna ( $\mathrm{SNr} / \mathrm{GPi}$ ) projections] and "indirect" [consisting of striatal to globus pallidus externa (GPe) to subthalamic nucleus (STN) projections] pathways is integrated to produce an inhibi- 


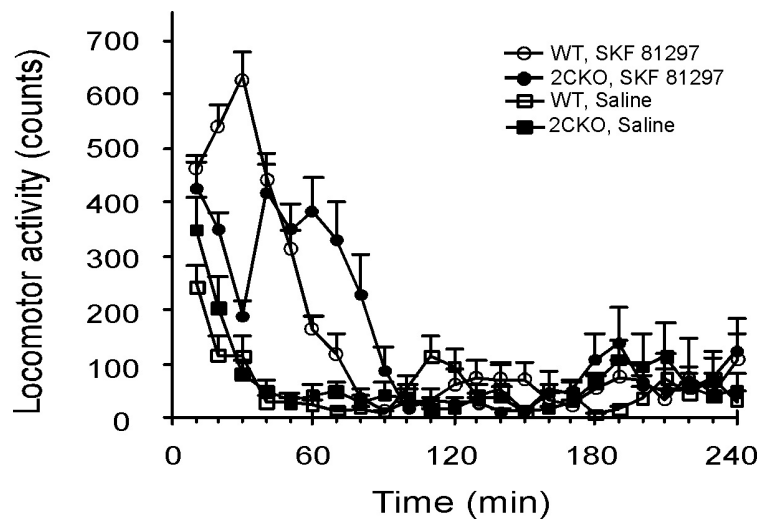

Figure 7. $5-\mathrm{HT}_{2} \mathrm{R}$ mutant mice display decreased locomotion in response to systemic treatment with the $D_{1}$ R agonist SKF 81297. Repeated-measures ANOVA on locomotor distance traveled between 0 and 90 min after injection revealed significant effects of time $\left(F_{(1,25)}=39.1\right.$, $p<0.001)$ and time $\times$ genotype $\left(F_{(1,25)}=4.65, p<0.05\right)$ and time $\times$ treatment $\left(F_{(2,25)}=\right.$ $5.89, p<0.01)$ interactions. There was also a significant time $\times$ genotype $\times$ treatment interaction $\left(F_{(2,25)}=10.69, p<0.001\right)$. ANOVA conducted on peak activity showed significant effects of genotype $\left(F_{(1,25)}=23.49, p<0.001\right)$, treatment $\left(F_{(2,25)}=60.46, p<0.001\right)$, and genotype $X$ treatment interaction $\left(F_{(2,25)}=22.06, p<0.001\right)$. Data are represented as mean \pm SEM. $n=6-7$ per group.

tory output that is fed back to thalamocortical motor centers (Graybiel, 2004). In addition to its expression in the SNc and DSt components of these circuits, $5-\mathrm{HT}_{2 \mathrm{C}} \mathrm{Rs}$ are highly expressed in the STN and SNr/GPi (Pompeiano et al., 1994; Wright et al., 1995; Eberle-Wang et al., 1997). Serotonin applied to STN neurons in slice preparations evokes a large inward current that can be blocked by $5-\mathrm{HT}_{2 \mathrm{C}} \mathrm{R}$ antagonists (Shen et al., 2007). This is accompanied by increases in cell firing (Fox et al., 1998; Stanford et al., 2005; Invernizzi et al., 2007; Shen et al., 2007). Furthermore, serotonin applied to $\mathrm{SNr}$ neurons in slice preparations evokes an excitatory inward current that is blocked by $5-\mathrm{HT}_{2 \mathrm{C}} \mathrm{R}$ antagonists (Stanford and Lacey, 1996). Therefore, decreases in $5-\mathrm{HT}_{2 \mathrm{C}} \mathrm{R}$ function could decrease $\mathrm{SNr}$ activity. The extent to which functional perturbations within the STN and GPi contribute to the phenotypic abnormalities observed here warrants further investigation.

We conclude that $5-\mathrm{HT}_{2 \mathrm{C}} \mathrm{Rs}$ have a substantial role controlling the nigrostriatal dopaminergic system and the behaviors it regulates. Previous studies have already shown that $5-\mathrm{HT}_{2 \mathrm{C}} \mathrm{Rs}$ have a role in mesoaccumbal dopaminergic system physiology. $5-\mathrm{HT}_{2 \mathrm{C}} \mathrm{Rs}$ are thus key regulators of the two major CNS ascending dopaminergic systems, and may play an important role integrating serotonergic and dopaminergic signaling. $5-\mathrm{HT}_{2 \mathrm{C}} \mathrm{Rs}$ may thus prove to be a clinically relevant target for the development of drugs to treat CNS disorders in which dopaminergic systems have been implicated (Di Matteo et al., 1999), including schizophrenia, substance abuse, attention-deficit/hyperactivity disorder, Parkinson's disease, and drug-induced movement disorders.

\section{References}

Aldridge JW, Berridge KC (1998) Coding of serial order by neostriatal neurons: a "natural action" approach to movement sequence. J Neurosci $18: 2777-2787$.

Aldridge JW, Berridge KC, Rosen AR (2004) Basal ganglia neural mechanisms of natural movement sequences. Can J Physiol Pharmacol 82:732-739.

Alex KD, Pehek EA (2007) Pharmacologic mechanisms of serotonergic regulation of dopamine neurotransmission. Pharmacol Ther 113:296-320.

Alex KD, Yavanian GJ, McFarlane HG, Pluto CP, Pehek EA (2005) Modulation of dopamine release by striatal 5 -HT2C receptors. Synapse $55: 242-251$.
Berridge KC, Aldridge JW (2000) Super-stereotypy II: enhancement of a complex movement sequence by intraventricular dopamine D1 agonists. Synapse 37:205-215.

Berridge KC, Aldridge JW, Houchard KR, Zhuang X (2005) Sequential super-stereotypy of an instinctive fixed action pattern in hyperdopaminergic mutant mice: a model of obsessive compulsive disorder and Tourette's. BMC Biol 3:4.

Blackburn TP, Minabe Y, Middlemiss DN, Shirayama Y, Hashimoto K, Ashby CR Jr (2002) Effect of acute and chronic administration of the selective 5-HT2C receptor antagonist SB-243213 on midbrain dopamine neurons in the rat: an in vivo extracellular single cell study. Synapse 46:129-139.

Blackburn TP, Suzuki K, Ashby CR Jr (2006) The acute and chronic administration of the $5-\mathrm{HT}(2 \mathrm{~B} / 2 \mathrm{C})$ receptor antagonist SB-200646A significantly alters the activity of spontaneously active midbrain dopamine neurons in the rat: An in vivo extracellular single cell study. Synapse 59:502-512.

Bobillier P, Pettijean F, Salvert D, Ligier M, Seguin S (1975) Differential projections of the nucleus raphe dorsalis and nucleus raphe centralis as revealed by autoradiography. Brain Res 85:205-210.

Bubar MJ, Cunningham KA (2007) Distribution of serotonin 5-HT2C receptors in the ventral tegmental area. Neuroscience 146:286-297.

Bunney BS, Walters JR, Roth RH, Aghajanian GK (1973) Dopaminergic neurons: effects of antipsychotic drugs and amphetamine on single cell activity. J Pharmacol Exp Ther 185:560-571.

Chartoff EH, Marck BT, Matsumoto AM, Dorsa DM, Palmiter RD (2001) Induction of stereotypy in dopamine-deficient mice requires striatal D1 receptor activation. Proc Natl Acad Sci U S A 98:10451-10456.

Creese I, Iversen SD (1973) Blockage of amphetamine induced motor stimulation and stereotypy in the adult rat following neonatal treatment with 6-hydroxydopamine. Brain Res 55:369-382.

Cromwell HC, Berridge KC (1996) Implementation of action sequences by a neostriatal site: a lesion mapping study of grooming syntax. J Neurosci $16: 3444-3458$.

De Deurwaerdère P, Bonhomme N, Lucas G, Le Moal M, Spampinato U (1996) Serotonin enhances striatal dopamine outflow in vivo through dopamine uptake sites. J Neurochem 66:210-215.

De Deurwaerdère P, Spampinato U (1999) Role of serotonin2A and serotonin $2 \mathrm{~B} / 2 \mathrm{C}$ receptor subtypes in the control of accumbal and striatal dopamine release elicited in vivo by dorsal raphe nucleus electrical stimulation. J Neurochem 73:1033-1042.

De Deurwaerdère P, Navailles S, Berg KA, Clarke WP, Spampinato U (2004) Constitutive activity of the serotonin $2 \mathrm{C}$ receptor inhibits in vivo dopamine release in the rat striatum and nucleus accumbens. J Neurosci 24:3235-3241.

Di Giovanni G, De Deurwaerdére P, Di Mascio M, Di Matteo V, Esposito E, Spampinato U (1999) Selective blockade of serotonin-2C/2B receptors enhances mesolimbic and mesostriatal dopaminergic function: a combined in vivo electrophysiological and microdialysis study. Neuroscience 91:587-597.

Di Giovanni G, Di Matteo V, Di Mascio M, Esposito E (2000) Preferential modulation of mesolimbic vs. nigrostriatal dopaminergic function by serotonin $2 \mathrm{C} / 2 \mathrm{~B}$ receptor agonists: a combined in vivo electrophysiological and microdialysis study. Synapse 35:53-61.

Di Giovanni G, Di Matteo V, La Grutta V, Esposito E (2001) $\mathrm{m}$-Chlorophenylpiperazine excites non-dopaminergic neurons in the rat substantia nigra and ventral tegmental area by activating serotonin-2C receptors. Neuroscience 103:111-116.

Di Matteo V, Di Giovanni G, Di Mascio M, Esposito E (1998) Selective blockade of serotonin $2 \mathrm{C} / 2 \mathrm{~B}$ receptors enhances dopamine release in the rat nucleus accumbens. Neuropharmacology 37:265-272.

Di Matteo V, Di Giovanni G, Di Mascio M, Esposito E (1999) SB 242084, a selective serotonin $2 \mathrm{C}$ receptor antagonist, increases dopaminergic transmission in the mesolimbic system. Neuropharmacology 38:1195-1205.

Di Matteo V, Di Giovanni G, Di Mascio M, Esposito E (2000) Biochemical and electrophysiological evidence that RO 60-0175 inhibits mesolimbic dopaminergic function through serotonin2C receptors. Brain Res 865:85-90.

Di Matteo V, De Blasi A, Di Giulio C, Esposito E (2001) Role of 5-HT2C receptors in the control of central dopamine function. Trends Pharmacol Sci 22:229-232.

Di Matteo V, Cacchio M, Di Giulio C, Di Giovanni G, Esposito E (2002a) Biochemical evidence that the atypical antipsychotic drugs clozapine and 
risperidone block 5-HT(2C) receptors in vivo. Pharmacol Biochem Behav 71:607-613.

Di Matteo V, Cacchio M, Di Giulio C, Esposito E (2002b) Role of serotonin2C receptors in the control of brain dopaminergic function. Pharmacol Biochem Behav 71:727-734.

Di Matteo V, Pierucci M, Esposito E (2004) Selective stimulation of serotonin $2 \mathrm{C}$ receptors blocks the enhancement of striatal and accumbal dopamine release induced by nicotine administration. J Neurochem 89:418-429.

Eberle-Wang K, Lucki I, Chesselet MF (1996) A role for the subthalamic nucleus in 5-HT2C-induced oral dyskinesia. Neuroscience 72:117-128.

Eberle-Wang K, Mikeladze Z, Uryu K, Chesselet MF (1997) Pattern of expression of the serotonin $2 \mathrm{C}$ receptor messenger RNA in the basal ganglia of adult rats. J Comp Neurol 384:233-247.

Esposito E (2006) Serotonin-dopamine interaction as a focus of novel antidepressant drugs. Curr Drug Targets 7:177-185.

Fibiger HC, Miller JJ (1977) An anatomical and electrophysiological investigation of the serotonergic projection from the dorsal raphe nucleus to the substantia nigra in the rat. Neuroscience 2:975-987.

Fink KB, Göthert M (2007) 5-HT receptor regulation of neurotransmitter release. Pharmacol Rev 59:360-417.

Fox SH, Moser B, Brotchie JM (1998) Behavioral effects of 5-HT2C receptor antagonism in the substantia nigra zona reticulata of the 6-hydroxydopamine-lesioned rat model of Parkinson's disease. Exp Neurol 151:35-49.

Giorgetti M, Tecott LH (2004) Contributions of 5-HT(2C) receptors to multiple actions of central serotonin systems. Eur J Pharmacol 488:1-9.

Gobert A, Rivet JM, Lejeune F, Newman-Tancredi A, Adhumeau-Auclair A, Nicolas JP, Cistarelli L, Melon C, Millan MJ (2000) Serotonin(2C) receptors tonically suppress the activity of mesocortical dopaminergic and adrenergic, but not serotonergic, pathways: a combined dialysis and electrophysiological analysis in the rat. Synapse 36:205-221.

Grace AA, Bunney BS (1980) Nigral dopamine neurons: intracellular recording and identification with L-DOPA injection and histofluorescence. Science 210:654-656.

Grace AA, Bunney BS (1984) The control of firing pattern in nigral dopamine neurons: burst firing. J Neurosci 4:2877-2890.

Graybiel AM (2004) Network-level neuroplasticity in cortico-basal ganglia pathways. Parkinsonism Relat Disord 10:293-296.

Heikkila RE, Manzino L (1984) Behavioral properties of GBR 12909, GBR 13069 and GBR 13098: specific inhibitors of dopamine uptake. Eur J Pharmacol 103:241-248.

Hernández-López S, Bargas J, Surmeier DJ, Reyes A, Galarraga E (1997) $D_{1}$ receptor activation enhances evoked discharge in neostriatal medium spiny neurons by modulating an L-type $\mathrm{Ca}^{2+}$ conductance. J Neurosci 17:3334-3342.

Hervé D, Pickel VM, Joh TH, Beaudet A (1987) Serotonin axon terminals in the ventral tegmental area of the rat: fine structure and synaptic input to dopaminergic neurons. Brain Res 435:71-83.

Hooks MS, Jones DN, Holtzman SG, Juncos JL, Kalivas PW, Justice JB Jr (1994) Individual differences in behavior following amphetamine, GBR12909, or apomorphine but not SKF-38393 or quinpirole. Psychopharmacology (Berl) 116:217-225.

Hopf FW, Cascini MG, Gordon AS, Diamond I, Bonci A (2003) Cooperative activation of dopamine $D_{1}$ and $D_{2}$ receptors increases spike firing of nucleus accumbens neurons via G-protein $\beta \gamma$ subunits. J Neurosci 23:5079-5087.

Invernizzi RW, Pierucci M, Calcagno E, Di Giovanni G, Di Matteo V, Benigno A, Esposito E (2007) Selective activation of 5-HT(2C) receptors stimulates GABA-ergic function in the rat substantia nigra pars reticulata: a combined in vivo electrophysiological and neurochemical study. Neuroscience 144:1523-1535.

Kelland MD, Freeman AS, Chiodo LA (1990) Serotonergic afferent regulation of the basic physiology and pharmacological responsiveness of nigrostriatal dopamine neurons. J Pharmacol Exp Ther 253:803-811.
Kelland MD, Freeman AS, Rubin J, Chiodo LA (1993) Ascending afferent regulation of rat midbrain dopamine neurons. Brain Res Bull 31:539-546.

Matell MS, Berridge KC, Wayne Aldridge J (2006) Dopamine D1 activation shortens the duration of phases in stereotyped grooming sequences. Behav Processes 71:241-249. e mesoaccumbens circuit by serotonin 5-hydroxytryptamine (5-HT)2A and 5-HT2C receptors. J Neurosci 21:7781-7787.

Mengod G, Nguyen H, Le H, Waeber C, Lübbert H, Palacios JM (1990) The distribution and cellular localization of the serotonin $1 \mathrm{C}$ receptor mRNA in the rodent brain examined by in situ hybridization histochemistry. Comparison with receptor binding distribution. Neuroscience 35:577-591.

Navailles S, De Deurwaerdère P, Porras G, Spampinato U (2004) In vivo evidence that 5-HT2C receptor antagonist but not agonist modulates cocaine-induced dopamine outflow in the rat nucleus accumbens and striatum. Neuropsychopharmacology 29:319-326.

Nedergaard S, Bolam JP, Greenfield SA (1988) Facilitation of a dendritic calcium conductance by 5-hydroxytryptamine in the substantia nigra. Nature 333:174-177.

Parsons LH, Justice JB Jr (1994) Quantitative approaches to in vivo brain microdialysis. Crit Rev Neurobiol 8:189-220.

Paxinos G, Franklin KBJ (2001) The mouse brain in stereotaxic coordinates. San Diego: Academic.

Pompeiano M, Palacios JM, Mengod G (1994) Distribution of the serotonin 5-HT2 receptor family mRNAs: comparison between 5-HT2A and 5-HT2C receptors. Brain Res Mol Brain Res 23:163-178.

Porras G, Di Matteo V, Fracasso C, Lucas G, De Deurwaerdère P, Caccia S, Esposito E, Spampinato U (2002) 5-HT2A and 5-HT2C/2B receptor subtypes modulate dopamine release induced in vivo by amphetamine and morphine in both the rat nucleus accumbens and striatum. Neuropsychopharmacology 26:311-324.

Prisco S, Pagannone S, Esposito E (1994) Serotonin-dopamine interaction in the rat ventral tegmental area: an electrophysiological study in vivo. J Pharmacol Exp Ther 271:83-90.

Saito H, Matsumoto M, Togashi H, Yoshioka M (1996) Functional interactions between serotonin and other neuronal systems: focus on in vivo microdialysis studies. Jpn J Pharmacol 70:203-225.

Sanghera MK, Trulson ME, German DC (1984) Electrophysiological properties of mouse dopamine neurons: in vivo and in vitro studies. Neuroscience 12:793-801.

Shen KZ, Kozell LB, Johnson SW (2007) Multiple conductances are modulated by 5 -HT receptor subtypes in rat subthalamic nucleus neurons. Neuroscience 148:996-1003.

Stanford IM, Lacey MG (1996) Differential actions of serotonin, mediated by 5-HT1B and 5-HT2C receptors, on GABA-mediated synaptic input to rat substantia nigra pars reticulata neurons in vitro. J Neurosci 16:7566-7573.

Stanford IM, Kantaria MA, Chahal HS, Loucif KC, Wilson CL (2005) 5 -Hydroxytryptamine induced excitation and inhibition in the subthalamic nucleus: action at 5- $\mathrm{HT}(2 \mathrm{C}), 5-\mathrm{HT}(4)$ and $5-\mathrm{HT}(1 \mathrm{~A})$ receptors. Neuropharmacology 49:1228-1234.

Surmeier DJ, Bargas J, Hemmings HC Jr, Nairn AC, Greengard P (1995) Modulation of calcium currents by a D1 dopaminergic protein kinase/ phosphatase cascade in rat neostriatal neurons. Neuron 14:385-397.

Tecott LH, Sun LM, Akana SF, Strack AM, Lowenstein DH, Dallman MF, Julius D (1995) Eating disorder and epilepsy in mice lacking 5-HT2c serotonin receptors. Nature 374:542-546.

Wang RY (1981) Dopaminergic neurons in the rat ventral tegmental area. I. Identification and characterization. Behav Res Rev 3:123-140.

Ward RP, Dorsa DM (1996) Colocalization of serotonin receptor subtypes 5-HT2A, 5-HT2C, and 5-HT6 with neuropeptides in rat striatum. J Comp Neurol 370:405-414.

Wright DE, Seroogy KB, Lundgren KH, Davis BM, Jennes L (1995) Comparative localization of serotonin $1 \mathrm{~A}, 1 \mathrm{C}$, and 2 receptor subtype mRNAs in rat brain. J Comp Neurol 351:357-373.

Yates JW, Meij JT, Sullivan JR, Richtand NM, Yu L (2007) Bimodal effect of amphetamine on motor behaviors in C57BL/6 mice. Neurosci Lett 427: $66-70$. 